\title{
The essence of the controversy between proponents of pro-choice and pro-life attitudes
}

\author{
Andrzej Brodziak ${ }^{1 *}$, Alicja Różyk Myrta ${ }^{2}$ and Jana Kutnohorska ${ }^{3}$ \\ ${ }^{1}$ Institute of Occupational Medicine and Environmental Health, Sosnowiec, Europe \\ ${ }^{2}$ Institute of Nursing, University of Applied Sciences, Europe \\ ${ }^{3}$ Department of Health Care Studies, Tomas Bata University, Europe
}

Submission: July 17, 2017; Published: July 26, 2017

*Corresponding author: Andrzej Brodziak, Institute of Occupational Medicine and Environmental Health, Koscielna St. 13, 41 - 200 Sosnowiec, Poland, Europe, Tel: (48 32) 26608 85; Fax: (48 32) 26611 24, Email: andrzejbrodziak@wp.pl

\section{Introduction}

Today in various countries around the world there is a dispute on the acceptability and legality of abortion. In Poland in October 2016, the contestation took the form of mass street protests. Understanding of causes of the ongoing culture war would require a review of the historical development of views on the acceptability of abortion [1]. However, the most important element of the problem is the essence of philosophical arguments to which the participants of the dispute refer.

The main philosophical arguments of the two parties of the dispute

The unique mention of abortion in the Old Testament is the following passage 21: 22 of the Book of Exodus: Exodus 21: 22. If people are fighting and hit a pregnant woman and she gives birth prematurely but there is no serious injury, the offender must be fined whatever the woman's husband demands and the court allows 23. But if there is serious injury, you are to take life for life, Eye for eye, tooth for tooth, hand for hand, foot for foot] St. Augustine (354-430 AD), one of the most influential Catholic theologians of the middle Ages promoted the concept of «delayed ensoulment.» He wrote that a human soul cannot live in an unformed body. Thus, an abortion in early in pregnancy according to him is not murder [2]. The influential, well-known theologian, founder of the dogmatic foundations of Christianity, Thomas Aquinas (1225 - 1274 AD), presented similar opinion [2]. The hierarchs of the Catholic Church began to take a more assertive, unfavorable position on the practice of abortion only in the sixteenth century.

The disputes of theologians have been undertaken by contemporary professional philosophers.
In his well-known article, KE Himma argues that under dualist assumptions about the nature of the mind, the fetus is not a person until brain activity has begun. He postulates that it is a necessary condition for an object to be a moral person that it has a self and he maintains that to have a self it is necessary to have an active brain, which manifests itself by its electrical activity [3].

This argument was carefully analyzed by FJ Beckwith [4]. He remarks that dualism can be seen from the other perspective, suggested already by Thomas Aquinas. The proponents of this concept assume that the human being is composed of the body and an immaterial substance animating all parts of the body. The immaterial substance is also called here the soul; nevertheless, it is not located in the brain only. This way of understanding dualism, called "the substance view", focuses on continuation of the existence of the human being since its beginning. Beckwith discusses the cases of anencephalic children and argues that the essence of a person is not necessarily bound with the brain, [4]. Nathan Nobis notes that the substance view tries to dilute the"Mentalistic, Consciousness Point of View" [5].

F Kissling, an activist of the movement "Catholics for a Free Choice (CFFC)" emphasize that "there is no decisive position within the Catholic Church on when the fetus becomes a person".

\section{Conclusion}

People involved in the dispute usually do not realize that in the records of religious dogma there is no data about the moral problem of abortion. The opinions of pro-life proponents are based mainly on the statements of Thomas Aquinas, derived from the ideas of Aristotle. The controversy is a result of the 
confrontation of these speculative arguments with the conscious dignity and rights of adult women.

\section{References}

1. Joffe C (2009) Abortion and medicine: A sociopolitical history. In M Paul: Management of unintended and abnormal pregnancy. John Wiley \& Sons Ltd, Oxford, UK.

2. Robinson BA (2017) Roman Catholicism and abortion access. Pagan \& Christian beliefs 400 BCE -1983 CE. Ontario Consultants on Religious Tolerance.
3. Himma KE (2003) What philosophy of mind can tell us about the morality of abortion: personhood, materialism, and the existence of self. Int J Appl Philos 17: 89-109.

4. Beckwith FJ (2005) Of souls, selves, and cerebrums: a reply to Himma. J Med Ethics 31(1): 56-60.

5. Nobis N (2011) Abortion, metaphysics and morality: a review of Francis Beckwith's defending life: a moral and legal case against abortion choice. J Med Philos 36(3): 261-273.

\begin{tabular}{|l|}
\hline \multicolumn{1}{|c|}{ Your next submission with Juniper Publishers } \\
will reach you the below assets \\
- Quality Editorial service \\
- Swift Peer Review \\
- Reprints availability \\
- E-prints Service \\
- Manuscript Podcast for convenient understanding \\
- Global attainment for your research \\
- Manuscript accessibility in different formats \\
( Pdf, E-pub, Full Text, Audio) \\
- Unceasing customer service \\
Track the below URL for one-step submission \\
https://juniperpublishers.com/online-submission.php \\
\hline
\end{tabular}

